\title{
Studies on Influence of Post Shooting Sprays of Nitrogen and Potassium on Quality Attributes of Banana cv. Grand Naine
}

\author{
G.C. Sandhya ${ }^{1^{*}}$, Kulapathi Hipparagi ${ }^{1}$, Sadanand K. Mushrif ${ }^{2}$, \\ Ashwini Ganur ${ }^{1}$ and P.M. Sampath ${ }^{3}$
}

${ }^{I}$ Department of Fruit Science, College of Horticulture, University of Horticultural Sciences, Udyanagiri, Bagalkot-587 104, Karnataka, India

${ }^{2}$ Department of Plant Pathology, College of Horticulture, Kolar, University of Horticultural Sciences, Bagalkot-587 104, Karnataka, India

${ }^{3}$ Department of Fruit Science, College of Horticulture, UHS Campus, G.K.V.K (Post), Bangalore-560 065, Karnataka, India

*Corresponding author

\section{A B S T R A C T}

\begin{tabular}{|l|}
\hline Ke y w o r d s \\
Grand Naine, Post \\
shooting spray, \\
Urea, SOP and \\
quality attributes \\
\hline Article Info \\
\hline $\begin{array}{l}\text { Accepted: } \\
\text { 26 February } 2018 \\
\text { Available Online: } \\
\text { 10 March } 2018\end{array}$ \\
\hline
\end{tabular}

\section{Introduction}

Banana (Musa sp.) is one of the oldest tropical fruits cultivated by man from the pre-historic time in India with great socio-economic significance. It is grown in all tropical regions and plays a key role in the economics of many developing countries. Banana and plantains are grown in about 120 countries. Globally,
A field experiment was carried out during 2015-16, in the farmer's field at Tulsigeri, Bagalkot district with a view to study the influence of post shooting sprays of nitrogen and potassium on quality attributes of banana $\mathrm{Cv}$. Grand Naine. The investigation comprised of eleven treatments, each replicated thrice in RCBD and the treatments consists of post shooting sprays of Urea $(1.00 \%, 1.50 \%$ and $2.00 \%)$, SOP (1.00\%, $1.50 \%$ and $2.00 \%)$, combination of urea and SOP, sprays as per the package of practice were sprayed thrice after emergence of flag leaf. There was a significant impact of potassium and nitrogen on all characters chosen for this study. The results of experiment revealed that marked improvement in fruit quality of banana cv. Grand Naine under post shooting spray of SOP $(2.00 \%)$ and urea $(1.00 \%)$ in three equal splits (T11) as reflected by the maximum values recorded in pulp weight $(115.67 \mathrm{~g})$, peel weight $(41.30 \mathrm{~g})$, TSS $\left(23.97{ }^{0} \mathrm{~B}\right)$ and total sugar $(18.35 \%)$. Whereas, highest ascorbic acid $(7 \mathrm{mg} / 100 \mathrm{~g})$ was reported in 2 per cent SOP (T8). Thus, the study clearly indicates that combined post-shoot spray of SOP $(2.00 \%)$ with $1.00 \%$ urea improves the quality of banana cv. Grand Naine. 
nutrients to be applied depends on the cultivar, initial soil fertility, stage of plant growth, climate etc. A judicious use of fertilizers not only gives high yield but also improves the quality of the fruit.

Now a days tissue culture banana cv. Grand Naine is acquiring lots of importance in all parts of Karnataka because of its better suitability, quality of planting material, uniformity in growth, earliness in flowering, uniformity in harvesting and tall stature which helps in better harvesting and better yield. Usually, tissue culture plants produce twice amount of roots than the normal plants. Hence, more nutrients will be absorbed by the plants to produce good yield. Under traditional farming system, banana crop receives its last dose of fertilizers (nitrogen and potassium) at $7^{\text {th }}$ month after planting i.e. just before shooting, which has to support the requirement of nutrients until harvest since large quantity of photosynthates are to move from the source to the sink i.e. developing bunches at this phase. Any limitation in the supply of nutrients at this crucial stage affects the bunch size and quality. Hence, an additional dose of fertilizer after shooting has become imperative. However, it is not advisable to go for soil application of fertilizers at finger development stage, since the uptake is slow and low at this stage (Veerannah et al., 1976).

Many reports have indicated the usefulness of post shooting spray of various nutrients during fruit development stage influencing the fruit yield, shelf life and quality (Kannan, 1980) and also banana has been found to respond well to potassium and nitrogen spray. If the size and quality of banana were high, which may in help to increase national or state economy. With these ideas, research was carried out to study the influence of post shooting sprays of nitrogen and potassium on quality attributes of banana cv. Grand Naine.

\section{Materials and Methods}

The research was conducted during 2015-16 in the farmer's field at Tulsigeri, Bagalkot district. The experiment was laid out in a Randomized Complete Block Design (RCBD) with eleven treatments, replicated thrice. Twelve plants were selected randomly for recording observations from each treatment.

The treatments were imposed to the crop during three different stages of crop growth. The first spray was given exactly at shooting, the unopened spadix were sprayed after the emergence of flag leaf. The second spray was given after the emergence of all the female flowers (after completion of female phase). The third spray was imposed to the bunches exactly one month after second spray.

The observation on quality parameters were recorded after the harvest of bunch which as follows:

\section{Pulp weight}

Pulp weight of ripened fruit was weighed after removing from peel using electronic balance and expressed in gram.

\section{Peel weight}

Peel weight of respective fruits was weighed and expressed in gram.

\section{Pulp to peel ratio}

The pulp to peel ratio was worked out by dividing the mean weight of pulp by mean weight of peel.

\section{Total soluble solids}

The total soluble solids was recorded with the extracted juice using a hand refractometer at room temperature and expressed in ${ }^{0}$ brix. 


\section{Ascorbic acid}

Ascorbic acid content was estimated titrimetrically using 2, 6-dichlorophenol indophenol dye as per the modified procedure of AOAC (Anon., 1984).

Ascorbic acid $(\mathrm{mg} / 100 \mathrm{~g})=[($ Ascorbic $(\mathrm{mg})$ in sample / $\mathrm{ml}$ of aliquot) $\mathrm{x}$ (V2 / V1) x (Total sample (ml) / Wt. of the sample)] x 100

\section{Total sugars}

The total sugar content of the fruit was estimated by following the method of Ranganna (1977) and expressed in percentage.

\section{Results and Discussion}

\section{Pulp weight and peel weight (g)}

The bunch sprayed with the nitrogen and potassium substances had significant effects on pulp and peel weight (Table 1 and Fig. 1).

The maximum pulp weight (115.67 g) and peel weight $(41.30 \mathrm{~g})$ were recorded in (T11) where, the bunch sprayed with two per cent sulphate of potash and one per cent urea. While, the minimum pulp weight $(109.33 \mathrm{~g})$ and peel weight $(35.67 \mathrm{~g})$ were recorded in control-water spray (T1).

Increase in pulp and peel weight might be due to efficient partitioning of carbohydrates and mobilization in developing bunches resulting in good pulp and peel recovery.

The accelerated rate of cell division and enlargement favoured by auxin biosynthesis prompted by nitrogen and potassium recorded higher pulp and peel weight (Mulagund et al., 2015). And also influence of potassium on filling of banana fingers has been registered by earlier workers like Mustaffa et al., (2004) in cv. Nendran.
The rate of photosynthesis is high in plants receiving adequate amounts of potassium. This may probably be due to the positive effect of potassium ions on the transfer of the products of photosynthesis, because it speeds up the flow of assimilates which results in increased production. The present results are similar to the findings of Madhu (2013) in banana cv. Grand Naine and Ramesh Kumar and Kumar (2007 and 2010) in banana cv. Neypoovan.

\section{Pulp: Peel ratio}

The data pertaining to pulp to peel ratio is furnished in Table 1. There was no significant difference between the treatments with pulp to peel ratio. However, pulp to peel ratio varied from 2.81 to 3.07. Similar results were also noticed by Nandan et al., (2011) in banana cv. Nanjangudu Rasabale and Tamilselvi (2006) in banana cv. Ney Poovan.

\section{Total soluble solids ( $\left.{ }^{0} \mathrm{Brix}\right)$}

Total soluble solids of fruit shown significant difference among the treatments and the data is presented in Table 2 .

The highest TSS (23.97 ${ }^{0}$ brix) was recorded in the treatment (T11) where, bunch sprayed with two per cent sulphate of potash and one per cent urea, while, the lowest TSS (18.98 brix) was recorded in control (T1).

Potassium has a prominent role in translocation of photo-assimilates; sugars and other soluble solids which are responsible for increased TSS in guava as reported by Mandal et al., (2012). Nandan et al., (2011) reported that increase in TSS due to sulphate of potash when supplied exogenously increased the flow of plant assimilates into the developing fruits especially when assimilate flow from other parts of plant becomes limited in banana cv. Nanjangudu Rasabale. 
Details of the treatments imposed during the experimentation

\begin{tabular}{|l|l|}
\hline Treatment No. & Treatment \\
\hline $\mathrm{T}_{1}$ & Control- Water spray \\
\hline $\mathrm{T}_{2}$ & Spraying as per POP (2,4-D 30ppm) \\
\hline $\mathrm{T}_{3}$ & Spraying of $1.00 \%$ Urea \\
\hline $\mathrm{T}_{4}$ & Spraying of $1.50 \%$ Urea \\
\hline $\mathrm{T}_{5}$ & Spraying of $2.00 \%$ Urea \\
\hline $\mathrm{T}_{6}$ & Spraying of $1.00 \%$ SOP \\
\hline $\mathrm{T}_{7}$ & Spraying of $1.50 \%$ SOP \\
\hline $\mathrm{T}_{8}$ & Spraying of $2.00 \%$ SOP \\
\hline $\mathrm{T}_{9}$ & Spraying of $1.00 \%$ SOP $+2.00 \%$ Urea \\
\hline $\mathrm{T}_{10}$ & Spraying of $1.50 \%$ SOP $+1.50 \%$ Urea \\
\hline $\mathrm{T}_{11}$ & Spraying of $2.00 \%$ SOP $+1.00 \%$ Urea \\
\hline
\end{tabular}

POP-Package of practices, SOP- Sulphate of potash

Table.1 Effect of post shooting spray on pulp to peel ratio of banana cv. Grand Naine

\begin{tabular}{|c|c|c|c|c|}
\hline $\begin{array}{l}\text { Tr. } \\
\text { No. }\end{array}$ & Treatment & $\begin{array}{l}\text { Pulp weight } \\
\text { (g) }\end{array}$ & $\begin{array}{l}\text { Peel weight } \\
\text { (g) }\end{array}$ & $\begin{array}{l}\text { Pulp to peel } \\
\text { ratio }\end{array}$ \\
\hline $\mathbf{T}_{1}$ & Control- Water spray & 109.33 & 35.67 & 3.07 \\
\hline $\mathbf{T}_{2}$ & Package of practice- 2,4-D (30ppm) & 114.37 & 39.68 & 2.89 \\
\hline $\mathbf{T}_{\mathbf{3}}$ & Urea $(1.00 \%)$ & 114.65 & 40.06 & 2.87 \\
\hline $\mathbf{T}_{4}$ & Urea $(1.50 \%)$ & 112.67 & 39.44 & 2.86 \\
\hline$T_{5}$ & Urea $(2.00 \%)$ & 110.33 & 37.52 & 2.94 \\
\hline$T_{6}$ & Sulphate of potash $(1.00 \%)$ & 110.33 & 38.00 & 2.90 \\
\hline $\mathbf{T}_{7}$ & Sulphate of potash $(1.50 \%)$ & 112.64 & 39.07 & 2.89 \\
\hline $\mathbf{T}_{8}$ & Sulphate of potash $(2.00 \%)$ & 114.67 & 40.86 & 2.81 \\
\hline $\mathbf{T}_{9}$ & Sulphate of potash $(1.00 \%)+$ Urea $(2.00 \%)$ & 112.00 & 38.24 & 2.93 \\
\hline$T_{10}$ & Sulphate of potash $(1.50 \%)+$ Urea $(1.50 \%)$ & 112.73 & 38.67 & 2.92 \\
\hline \multirow[t]{3}{*}{$\mathrm{T}_{11}$} & Sulphate of potash $(2.00 \%)+$ Urea $(1.00 \%)$ & 115.67 & 41.30 & 2.81 \\
\hline & S.Em. \pm & 0.85 & 0.78 & 0.06 \\
\hline & C.D. at $5 \%$ & 2.50 & 2.29 & NS \\
\hline
\end{tabular}

NS: Not significant 
Table.2 Effect of post shooting spray on post-harvest parameters of banana cv. Grand Naine

\begin{tabular}{|c|c|c|c|c|}
\hline $\begin{array}{l}\text { Tr. } \\
\text { No. }\end{array}$ & Treatment & TSS ( ${ }^{0}$ Brix) & $\begin{array}{l}\text { Ascorbic } \\
\text { acid (mg/100 } \\
\text { g) }\end{array}$ & $\begin{array}{l}\text { Total sugar } \\
(\%)\end{array}$ \\
\hline $\mathbf{T}_{1}$ & Control- Water spray & 18.98 & 5.81 & 15.79 \\
\hline $\mathbf{T}_{2}$ & Package of practice- 2,4-D (30ppm) & 23.08 & 6.83 & 17.74 \\
\hline$\overline{T_{3}}$ & Urea $(1.00 \%)$ & 23.54 & 6.80 & 18.09 \\
\hline $\mathbf{T}_{4}$ & Urea $(1.50 \%)$ & 20.34 & 6.29 & 16.59 \\
\hline $\mathbf{T}_{5}$ & Urea $(2.00 \%)$ & 20.19 & 6.02 & 16.24 \\
\hline $\mathrm{T}_{6}$ & Sulphate of potash $(1.00 \%)$ & 21.38 & 6.56 & 16.68 \\
\hline $\mathbf{T}_{7}$ & Sulphate of potash $(1.50 \%)$ & 23.51 & 6.59 & 17.08 \\
\hline $\mathbf{T}_{8}$ & Sulphate of potash $(2.00 \%)$ & 23.72 & 7.00 & 18.21 \\
\hline $\mathbf{T}_{9}$ & Sulphate of potash $(1.00 \%)+$ Urea $(2.00 \%)$ & 21.71 & 6.42 & 17.05 \\
\hline $\mathbf{T}_{10}$ & Sulphate of potash $(1.50 \%)+$ Urea $(1.50 \%)$ & 22.83 & 6.55 & 17.21 \\
\hline \multirow[t]{3}{*}{$\mathbf{T}_{11}$} & Sulphate of potash $(2.00 \%)+$ Urea $(1.00 \%)$ & 23.97 & 6.81 & 18.35 \\
\hline & S.Em.土 & 0.34 & 0.12 & 0.11 \\
\hline & C.D. at $5 \%$ & 1.01 & 0.35 & 0.32 \\
\hline
\end{tabular}

Fig.1 Effect of post shooting sprays on pulp and peel weight (g) of banana cv. Grand Naine

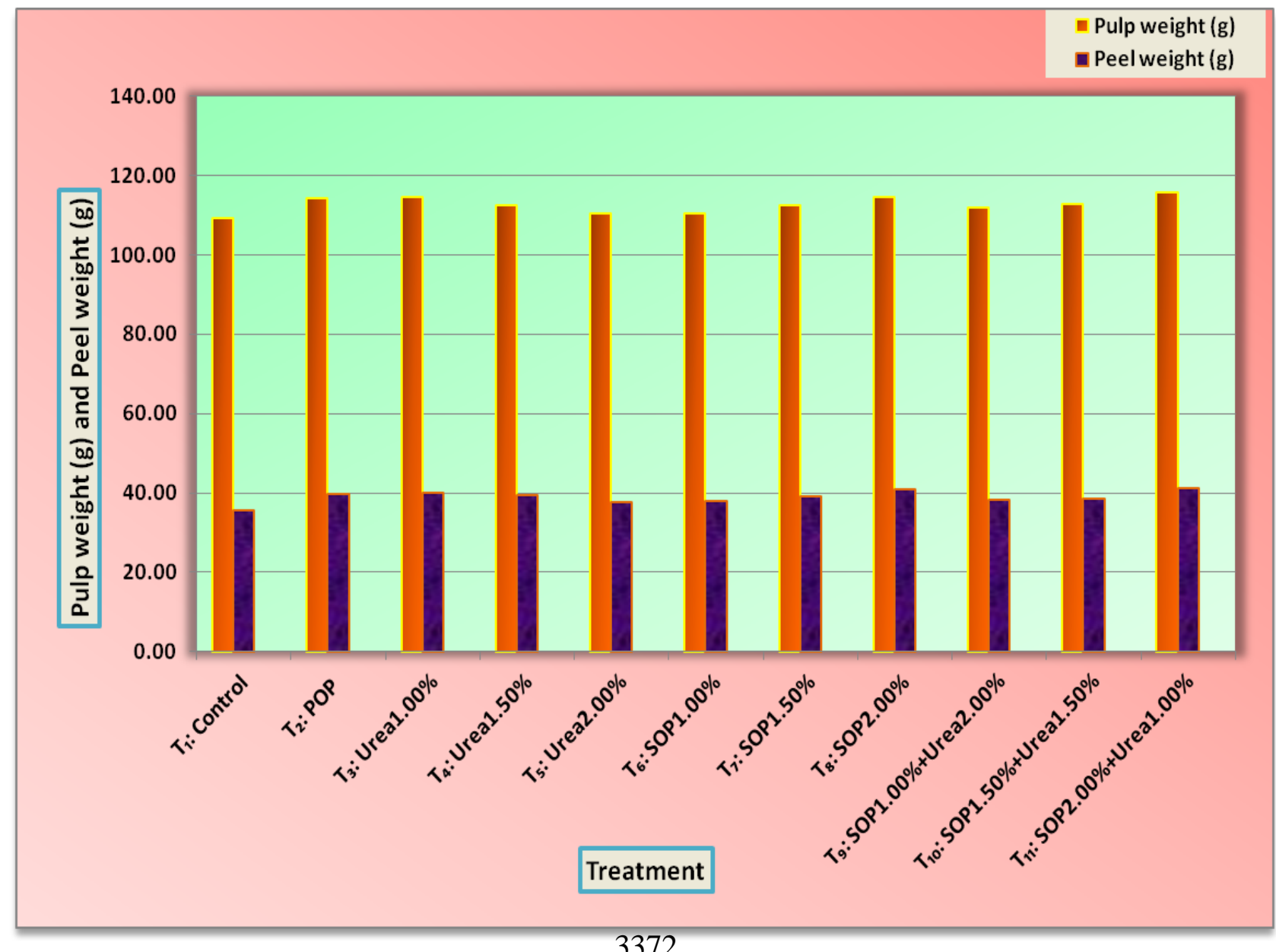


Fig.2 Effect of post shooting spray on total sugar (\%) of banana cv. Grand Naine

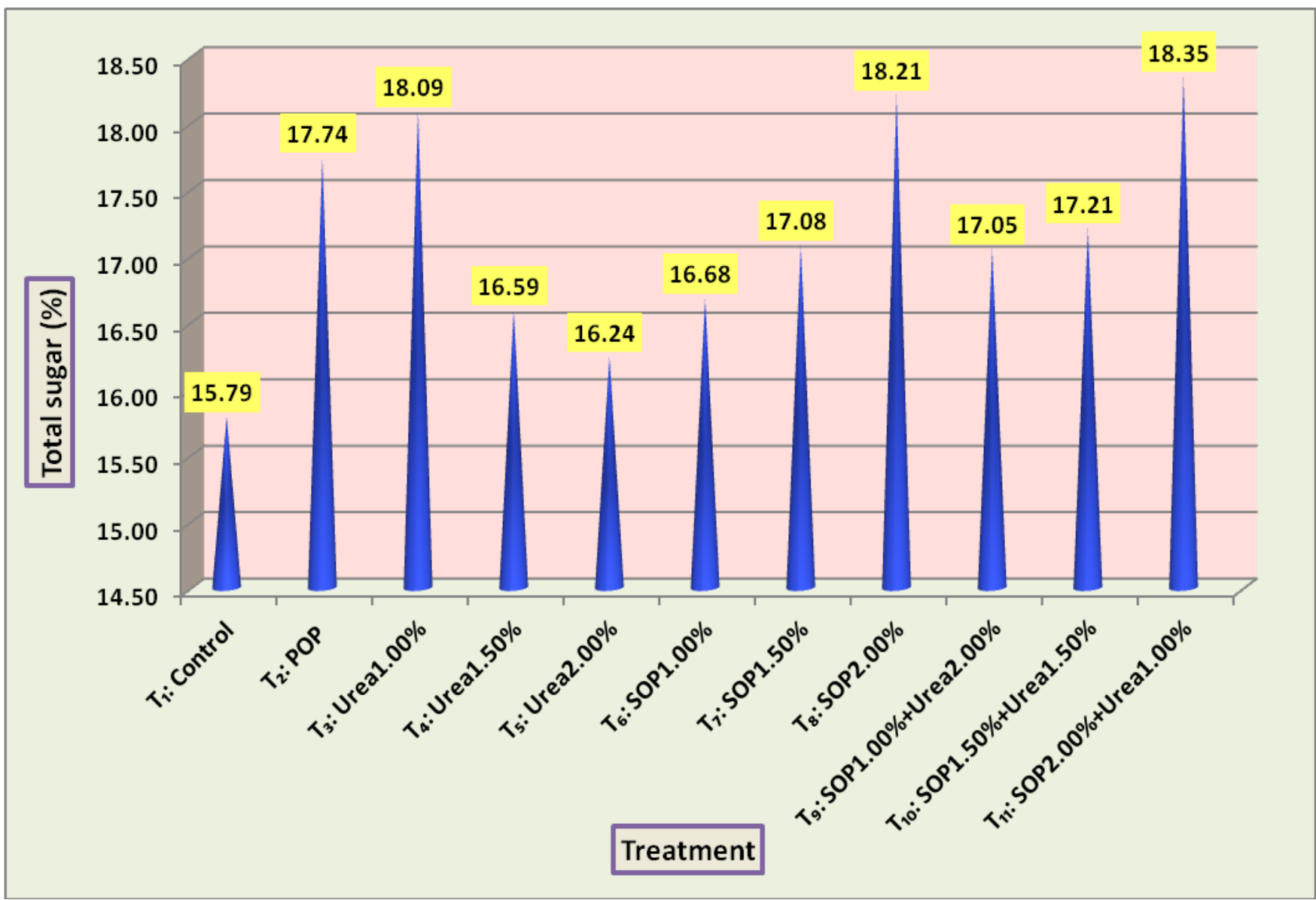

Plate.1 Best performed treatment

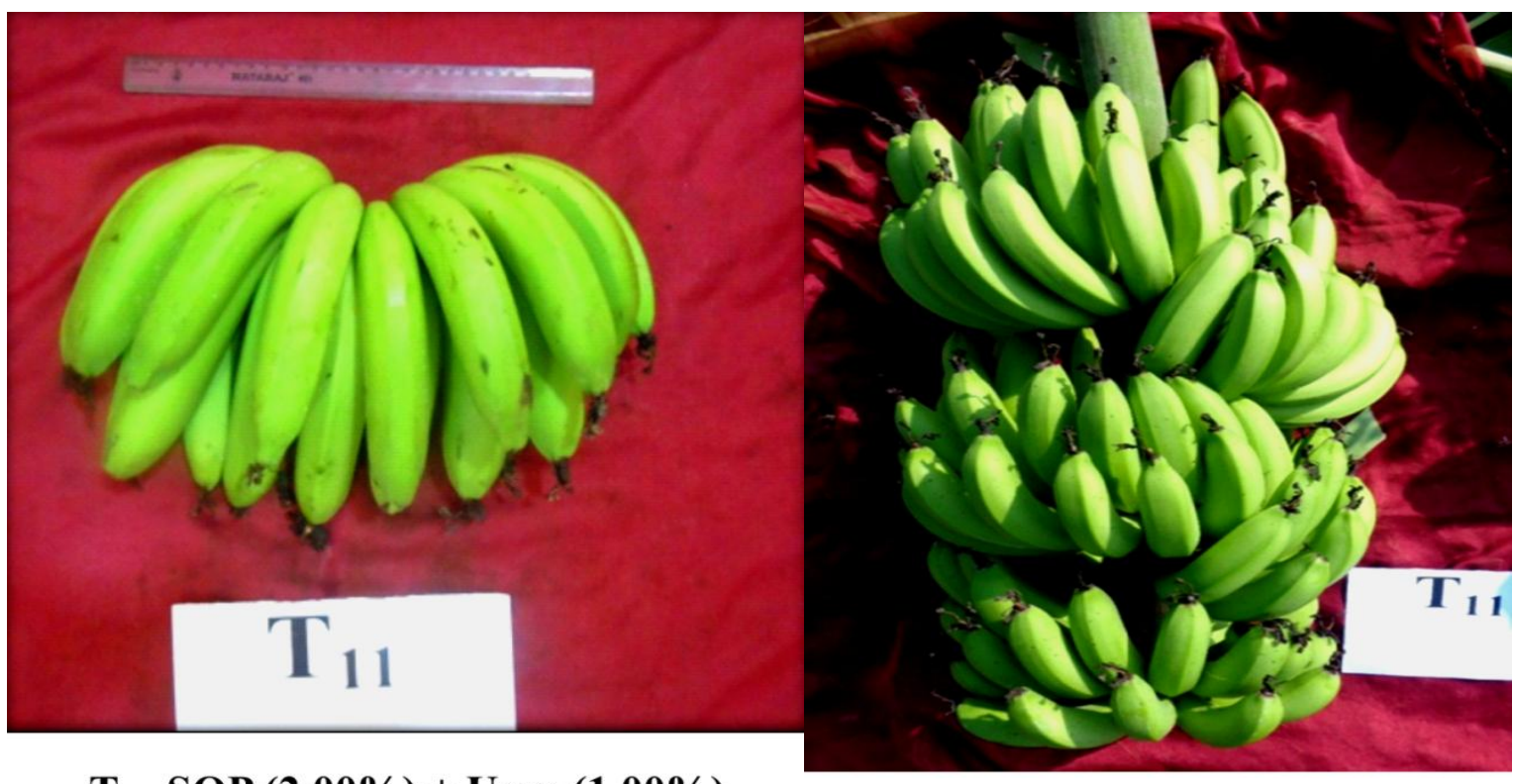

$T_{11}-\operatorname{SOP}(2.00 \%)+$ Urea $(1.00 \%)$

$T_{11}-\operatorname{SOP}(2.00 \%)+$ Urea $(1.00 \%)$ 


\section{Ascorbic acid (mg/100g)}

The ascorbic acid content was found to differ significantly among the treatments and the data on ascorbic acid are presented in Table 2. The highest ascorbic acid content (7 $\mathrm{mg} / 100 \mathrm{~g}$ ) was recorded in the treatment (T8) where, bunch sprayed with two per cent sulphate of potash. While, the lowest ascorbic acid $(5.81 \mathrm{mg} / 100 \mathrm{~g})$ was recorded in controlwater spray (T1).

Increased ascorbic acid content might be due to the presence of potassium and sulphur which could have helped to slow down the enzyme system that encouraged the oxidation of ascorbic acid, thus helping the plants to accumulate more ascorbic acid content in the fruits (Ananthi et al., 2004). The high energy status in crops well supplied with $\mathrm{K}$ also promotes synthesis of secondary metabolites, like Vitamin C (Mengel, 1997).

\section{Total sugar (\%)}

The effects of different post shooting spray treatments were found to increase the total sugar percentage significantly and the data are furnished in Table 2 and Figure 2. Among the treatments, the highest total sugar $(18.35 \%)$ was recorded in T11 where, bunch sprayed with two per cent sulphate of potash and one per cent urea, while, the lowest total sugar $(15.79 \%)$ was recorded in control (T1). Potassium when supplied in form of sulphate of potash favours conversion of starch into simple sugars during ripening activating the sucrose synthetase enzyme thus resulting in higher sugar percentage as reported by Ramesh Kumar and Kumar (2007).

\section{Acknowledgement}

University of Horticultural Sciences, Bagalkot for their co-opertion in conducting research is acknowledged.

\section{References}

Ananthi, S., Veeraragavathatham, D. and Srinivasan, K., 2004. Comparative efficacy of sulphate of potash and muriate of potash on yield and quality of chilli (Capsicum annuum L.). South Indian Hort. 52: 158-63.

Anon, 1984. Official Methods of Analysis. ED. Sioney Williams, Associat. Official Analytical Virginia, $14^{\text {th }}$ Edition, pp. 423-462.

Kannan, S., 1980. Mechanism of foliar uptake of plant nutrients: Accomplishments and prospects. J. Pl. Nutr. 2: 717-735.

Madhu, R., 2013. Effect of bunch spray of nitrogen and potassium on yield and quality of banana cv. Grand Naine under hill zone of Karnataka. M.Sc. (Hort) Thesis. Uni. Agril. Sci., Bangalore, India.

Mandal, G., Dhaliwal, H. S. and Mahajan, B. V. C., 2012. Effect of pre-harvest application of NAA and potassium nitrate on storage quality of winter guava (Psidium guajava). Indian $J$. Agric. Sci. 82(11): 985- 989.

Mengel, K. 1997. In food security in the WANA region, the essential need for balance fertilization (Ed. Johnston, A.E.). Proc. Regional Workshop, Turkey. pp. 157-174.

Mulagund, J. S., Kumar, K., Soorianathasundaram and Harikanth Porika, 2015. Influence of post-shooting sprays of sulphate of potash and certain growth regulators on bunch characters and fruit yield of banana cv. Nendran (French plantain Musa AAB). The Bioscan. 10(1): 153-159.

Mustaffa M. M., Tanuja, B., Sivakumar, K. C., Kumar, V. and Sathiamoorthy S., 2004. Effect of preharvest treatments on bunch parameters, quality and shelf life of banana cv. Nendran. In Banana: Technological Advancements (Singh, $\mathrm{H}$. 
P., and Uma, S. Eds.), AIPUB, Trichy. pp. 124-132.

Nandan, C. P., Sathyanarayana, B. N., Naresh, P. and Lakshmipathy, M., 2011. Effect of certain pre harvest treatments in improving the yield and quality of banana cv. Nanjangudu Rasabale. $P l$. Arc. 11(2): 677-681.

Ramesh Kumar, A. and Kumar, N., 2007. Sulphate of potash foliar spray effects on yield, quality and post-harvest life of banana (India). Better Crops. 91(2): 2224.

Ramesh Kumar, A. and Kumar, N., 2010. Effect of post-shooting spray of certain nutrients on yield and quality of banana cv. Neypoovan (AB). Agric. Sci. Digest. 30(2): 125- 128.

Ranganna, S., 1977. Manual of Analysis of Fruit and Vegetable Products. Tata Mc Grow Hill Publ., Co., Ltd., New Delhi.

Tamilselvi, C., 2006. Effect of certain plant growth regulator on growth parameters and fruit yield of banana cv. Ney Poovan. South Indian Hort. pp. 223228.

Veerannah, L., Selvaraj, P. and Azhakiamanavalan, R. S., 1976. Studies on the nutrient uptake in Robusta and Poovan. Indian J. Hort. 33: 203-208.

\section{How to cite this article:}

Sandhya, G.C., Kulapathi Hipparagi, Sadanand K. Mushrif, Ashwini Ganur and Sampath, P.M. 2018. Studies on Influence of Post Shooting Sprays of Nitrogen and Potassium on Quality Attributes of Banana cv. Grand Naine. Int.J.Curr.Microbiol.App.Sci. 7(03): 3368-3375.

doi: https://doi.org/10.20546/ijcmas.2018.703.389 